\title{
PENGEMBANGAN MULTIMEDIA PEMBELAJARAN INTERAKTIF DENGAN TEMA PENGENALAN HURUF HIJAIYAH UNTUK PESERTA DIDIK SEKOLAH DASAR
}

\author{
Wanda Ramansyah \\ Universitas Trunojoyo Madura \\ Bangkalan, Indonesia \\ wandaramansyah@hotmail.com
}

\begin{abstract}
Abstrak
Mata pelajaran Pendidikan Agama Islam dengan tema Huruf Hijaiyah adalah mata pelajaran yang mengajarkan peserta didik tentang pengenalan Huruf Hijaiyah dan pelafalan Huruf Hijaiyah. Dilihat dari karakter pembelajarannya maka materi dalam mata pelajaran membahas tentang bentuk dan cara menyebut Huruf Hijaiyah. Permasalahan muncul karena belajar menggunakan buku dirasa kurang baik karena buku hanya menyajikan gambar bentuk huruf tanpa menampilkan suara cara membaca Huruf Hijaiyah yang benar. Multimedia pembelajaran interaktif akan menyelesaikan permasalahan ini dengan menyediakan animasi bergerak tentang Huruf Hijaiyah yang menyajikan visualisasi bentuk huruf diserta audio cara pelafalan huruf. Dengan adanya multimedia pembelajaran interaktif maka peserta didik akan lebih mudah dan cepat memahami materi pelajaran, selain itu proses pembelajaran akan lebih menarik dan menyenangkan.
\end{abstract}

Kata Kunci: multimedia, interaktif, Huruf Hijaiyah

\begin{abstract}
Subjects of Islamic Religious Education with the theme HijaiyahLettersare subjects that teach students about recognition and pronunciation Letter HijaiyahLettersHijaiyah. Judging from the character of the learning material in the subjects discussed on the form and manner Hijaiyah call letters. Problems arise because learning to use the book is less good because the book only provides shape without featuring the voices reading letters Hijaiyah correct. Multimedia interactive learning would solve this problem by providing a moving animation about the letters Hijaiyah serving visualization of the form letter accompanied way audio pronunciation of letters. With the multimedia interactive learning, the learners will be more easily and quickly understand the subject matter, in addition, the learning process will be more interesting and fun.
\end{abstract}

Keywords: multimedia, interactive, Hijaiyah Letters 


\section{PENDAHULUAN}

Al-Quran dalam Agama Islam adalah pedoman hidup bagi orang beragama Islam yang digunakan menjadi dasar-dasar dalam menjalani kehidupan di dunia, baik dalam kegiatan beribadah maupun dalam kehidupan sehari-hari. Semua umat Islam di seluruh penjuru dunia wajib bisa membaca dan menulis Al-Quran sejak kecil karena Al-Quran sebagai kitab suci umat Islam hanya tersaji dalam Bahasa Arab. Tidak ada Al-Quran yang menggunakan bahasa selain Bahasa Arab kecuali terjemahannya. Al-Quran dalam penulisannya menggunakan Bahasa Arab yang mana menggunakan Huruf Hijaiyah.

Bagi umat Islam di Indonesia yang mana menggunakan Bahasa Indonesia tentu saja merupakan suatu hal yang asing jika berhadapan dengan Bahasa Arab, apalagi jika tidak mengenal Bahasa Arab dari kecil. Hal ini wajar karena Huruf dalam Bahasa Indonesia sangat berbeda jika dibandingkan dengan Huruf Hijaiyah. Oleh karena itu jika Huruf Hijaiyah tidak diajarkan sejak kecil mulai dari anak-anak maka di kemudian hari mereka akan kesulitan dalam membaca Al-Quran. Jika mereka kesulitan dalam membaca Al-Quran maka dalam beribadah sebagai umat beragama Islam tentu saja tidak bisa maksimal.

Ditinjau dari karakteristik pembelajaran Pendidikan Agama Islam dengan tema pengenalan Huruf Hijaiyah tersebut maka pembahasan lebih banyak mengupas tentang mengetahui Huruf Hijaiyah, menyebutkan Huruf Hijaiyah, dan melafalkan Huruf Hijaiyah dengan baik dan benar. Permasalahan timbul karena pembelajaran menggunakan buku tematik SD tentu saja dirasakan kurang, hal ini karena buku tersebut hanya menyajikan bentuk huruf saja tanpa menyebutkan cara pelafalan huruf-huruf secara jelas. Dalam hal ini peserta didik akan mengalami kesulitan mempelajari Huruf Hijaiyah jika mereka hanya melihat tulisan Huruf Hijaiyah di dalam buku.

Perkembangan teknologi informasi dan komunikasi yang sangat pesat mendorong berbagai lembaga pendidikan memanfaatkan kemajuan teknologi tersebut guna meningkatkan mutu pembelajaran. Media (selain guru) yang biasanya hanya menyajikan komunikasi satu arah, saat ini oleh perkembangan teknologi dapat dimodifikasi menjadi media yang menyajikan pembelajaran dua arah yang disebut dengan pembelajaran interaktif. Rob Phillips (1997:8) menjelaskan makna interaktif sebagai suatu proses pemberdayaan peserta didik untuk mengendalikan lingkungan belajar. Dalam konteks ini lingkungan belajar yang dimaksud adalah belajar dengan menggunakan komputer.

Pembelajaran yang bersifat interaktif akan memberikan banyak kelebihan di dalam pembelajaran. Karena bersifat interaktif maka akan terjadi pembelajaran dua arah, yaitu interaksi antara media pembelajaran dengan peserta didik. Pembelajaran interaktif adalah suatu pembelajaran yang dilengkapi dengan alat pengontrol yang dapat dioperasikan oleh peserta didik, sehingga peserta didik dapat memilih apa yang dikehendaki untuk proses selanjutnya.

Kondisi ideal yang diharapkan dalam pembelajaran mata pelajaran Pendidikan Agama Islam tema pengenalan Huruf Hijaiyah adalah tersedianya media pembelajaran yang dapat memudahkan peserta didik untuk belajar dan sekaligus dapat memotivasi dan meningkatkan daya tarik peserta didik untuk belajar. Namun kondisi riil yang dihadapi saat ini adalah masih kurang dan terbatasnya media yang digunakan guru dalam pembelajaran mata pelajaran Pendidikan Agama Islam tema pengenalan Huruf Hijaiyah. Kesenjangan antara kondisi ideal dan kondisi riil ini harus segera diatasi agar memudahkan peserta didik dalam belajar, motivasi dan daya tarik peserta didik dalam belajar dapat ditingkatkan, dan nilai hasil belajar dapat meningkat.

Keterbatasan buku Tematik SD untuk memfasilitasi peserta didik dalam belajar mata pelajaran Pendidikan Agama Islam tema pengenalan Huruf Hijaiyah harus segera diatasi 
dengan menggunakan media pembelajaran interaktif berbasis komputer. Dalam pembelajaran interaktif berbasis komputer ini akan disajikan pembelajaran yang sanggup memudahkan peserta didik dalam mempelajari mata pelajaran Pendidikan Agama Islam tema pengenalan Huruf Hijaiyah, hal itu dikarenakan dalam pembelajaran akan disajikan materi yang berupa multimedia (terdiri dari teks, suara, gambar, animasi, dan video) yang tentu saja akan menggambarkan secara nyata materi atau konten dalam mempelajari tema pengenalan Huruf Hijaiyah. Dengan menggunakan multimedia pembelajaran interaktif ini maka peserta didik akan dapat dengan mudah mempelajari materimateri dalam mata pelajaran Pendidikan Agama Islam tema pengenalan Huruf Hijaiyah. Multimedia sering dikaitkan dengan computer based learning karena di dalam multimedia digunakan perangkat komputer yang mampu menampilkan media yang beragam, seperti teks, gambar, suara, animasi, video, dan lain sebagainya. Oleh karena itu penyajian media pembelajaran yang beragam dalam suatu waktu disebut juga dengan multimedia pembelajaran.

Pengertian interaktif terkait dengan komunikasi dua arah atau lebih dari komponen-komponen komunikasi. Komponen komunikasi dalam multimedia interaktif (berbasis komputer) adalah hubungan antara manusia (sebagai user/pengguna produk) dan komputer (software/aplikasi/produk dalam format file tertentu, biasanya dalam bentuk CD). Dengan demikian produk/CD/aplikasi yang diharapkan memiliki hubungan dua arah atau timbal balik antara software/aplikasi dengan pemakai (user).

Rob Phillips (1997:8) menjelaskan makna interaktif sebagai suatu proses pemberdayaan peserta didik untuk mengendalikan lingkungan belajar. Dalam konteks ini lingkungan belajar yang dimaksud adalah belajar dengan menggunakan komputer. Klasifikasi interaktif dalam lingkup multimedia pembelajaran bukan terletak pada sistem hardware, tapi lebih mengacu pada karakteristik belajar peserta didik dalam merespon stimulus yang ditampilkan layar monitor komputer. Kualitas interaksi peserta didik dengan komputer sangat ditentukan oleh kecanggihan program komputer. Schweir dan Misanchuk (1993) menyatakan, sedikitnya ada tiga tingkatan yaitu (a) reaktif, (b) proaktif, dan (c) mutual interaksi.

Multimedia dalam pembelajaran interaktif akan memberikan gambaran yang jelas tentang mata pelajaran Pendidikan Agama Islam tema pengenalan Huruf Hijaiyah karena dapat menyajikan secara gamblang bentuk-bentuk Huruf Hijaiyah, cara penulisannya, dan cara melafalkan atau membaca huruf tersebut dengan benar, di mana hal tersebut tidak bisa difasilitasi oleh media pembelajaran yang berupa buku tematik SD.

Penerapan dan penggunaan kemajuan teknologi informasi dan multimedia dalam bidang pendidikan akan memberikan beberapa manfaat dalam proses pembelajaran, seperti:

- Sistem pembelajaran lebih inovatif dan interaktif. Pengajar akan selalu dituntut untuk kreatif inovatif dalam mencari terobosan pembelajaran.

- Mampu menggabungkan antara teks, gambar, audio, musik, animasi gambar atau video dalam satu kesatuan yang saling mendukung guna tercapainya tujuan pembelajaran.

- Membuat hal-hal yang abstrak menjadi konkret dan jelas. Penjelasan melalui multimedia (teks, gambar, animasi, maupun video) akan lebih mudah dipahami peserta didik jika dibandingkan dengan belajar dari buku teks saja.

- Mampu menimbulkan rasa senang selama proses pembelajaran berlangsung. Hal ini akan menambah motivasi peserta didik selama proses pembelajaran hingga didapatkan tujuan pembelajaran yang maksimal. 
- Mampu memvisualisasikan materi yang selama ini sulit untuk diterangkan hanya sekedar dengan penjelasan atau alat peraga yang konvensional.

- Media penyimpanan yang relatif mudah dan fleksibel.

- Pengenalan perangkat teknologi informasi dan komunikasi kepada peserta didik.

- Memberikan pengalaman baru dan menyenangkan baik bagi guru itu sendiri maupun peserta didik.

- Mengikuti dan mengejar ketertinggalan akan pengetahuan tentang ilmu pengetahuan dan teknologi di bidang pendidikan.

Karakteristik peserta didik jika dilihat dari gaya belajarnya terbagi dalam tiga jenis, yaitu: visual, auditori, dan kinestetik. Pembelajaran akan optimal jika media pembelajaran yang disajikan sesuai dengan karakteristik gaya belajar peserta didik. Gaya belajar visual identik dengan penglihatan, auditori identik dengan pendengaran, dan kinestetik identik dengan pergerakan atau praktek. Kemampuan multimedia pembelajaran interaktif dalam menyajikan teks, suara, gambar, animasi, dan video sekaligus dalam suatu media maka seluruh peserta didik dengan karakteristik yang berbeda akan dapat terlayani oleh media pembelajaran tersebut.

Penelitian pada tahun 2014 oleh Wanda Ramansyah selaku dosen di Program Studi Pendidikan Informatika FKIP Universitas Trunojoyo Madura dengan judul jurnal Pengembangan Multimedia Pembelajaran Interaktif Berbasis Adobe Flash CS3 Pada Kelas 1 SDN Bancaran 3 Bangkalan. Dalam penelitiannya Wanda Ramansyah menyimpulkan bahwa: (a) dari data yang dihasilkan saat uji coba perorangan diketahui bahwa rata-rata prosentase secara keseluruhan mengenai kualitas multimedia pembelajaran interaktif adalah $91,6 \%$ yang berarti berada pada kualifikasi "sangat tinggi" atau "sangat layak" dan tidak memerlukan revisi, (b) dari data yang dihasilkan saat uji coba kelompok kecil diketahui bahwa rata-rata prosentase secara keseluruhan mengenai kualitas multimedia pembelajaran interaktif adalah $88,6 \%$ yang berarti berada pada kualifikasi "tinggi" atau "baik" dan tidak memerlukan revisi, (c) dari data yang dihasilkan saat uji coba kelompok besar diketahui bahwa rata-rata prosentase secara keseluruhan mengenai kualitas multimedia pembelajaran interaktif adalah 88,6 \%yang berarti berada pada kualifikasi "tinggi" atau "baik" dan tidak memerlukan revisi.

Penelitian yang disampaikan dalam Seminar Nasional Kontribusi Pendidiakan Jarak Jauh (PJJ) dalam Pencapaian Milenium Development Golas (MDGs), Universitas Terbuka, Tangerang Banten, pada 10 Maret 2008 oleh Muhammad Adri dan Nelda Azhar sebagai staf pengajar Teknik Elektronika Fakultas Teknik Universitas Negeri Padang. Di mana judul penelitian yang disampaikan adalah Pengembangan Paket Multimedia Interaktif sebagai Sarana Belajar Mandiri Mahapeserta didik. Dalam penelitiannya mereka menyimpulkan bahwa: (a) E-Media berupa multimedia Fisika Terapan pada mahapeserta didik jurusan Teknik Elektronika dapat meningkatkan kemampuan belajar mandiri mahapeserta didik, sehingga memberikan keluwesan dan kebebasan bagi mahapeserta didikdalammengeksplorasi kemampuannya secara mandiri,(b) Penyusunan dan perancangan struktur materi (management course tools) merupakan langkah awal dalam menentukan tingkat ketercapaian pembuatan suatu E-Media berupa multimedia.

Dari hasil penelitian para ahli, ditemukan bahwa jika informasi disampaikan melalui gambar maka $65 \%$ dari apa yang diinformasikan tersebut dapat diingat oleh penonton, sedangkan jika disampaikan lewat suara hanya dapat diingat sebanyak $40 \%$ saja dari apa yang diinformasikan (Endang A, 
1997). Sedangkan menurut Dowyer dalam Sardiman (1995), televisi dan komputer yang menyajikan video atau animasi mampu merebut $94 \%$ saluran masuknya pesan atau informasi ke dalam jiwa manusia melalui mata dan telinga serta mampu untuk membuat orang pada umumnya mengingat $50 \%$ dari apa yang mereka lihat dan dengar dari tayangan program. Di sini tampak bahwa pesan yang disampaikan melalui media video dapat mempengaruhi emosi yang kuat dan juga dapat mencapai hasil cepat yang tidak dimiliki oleh media lain.

Dengan pemaparan fakta-fakta di atas maka perlu diciptakan multimedia pembelajaran interaktif menggunakan model pengembangan Kemp dan Dayton pada mata pelajaran Pendidikan Agama Islam tema pengenalan Huruf Hijaiyah. Di mana multimedia pembelajaran interaktif akan membantu peserta didik untuk mengetahui Huruf Hijaiyah, menyebutkan Huruf Hijaiyah, dan melafalkan Huruf Hijaiyah dengan mudah dan menyenangkan. Multimedia pembelajaran interaktif tersebut akan mampu mengatasi kesulitan peserta didik dalam belajar mata pelajaran Pendidikan Agama Islam tema pengenalan Huruf Hijaiyah dibandingkan dengan pembelajaran yang hanya menggunakan buku tematik SD saja.

Berdasarkan rumusan masalah yang telah dipaparkan di atas maka tujuan pengembangan ini adalah untuk mengatasi permasalahan belajar peserta didik dengan menciptakan media belajar berupa multimedia pembelajaran interaktif pada pembelajaran mata pelajaran Pendidikan Agama Islam tema pengenalan Huruf Hijaiyah yang bertujuan untuk membantu peserta didik Kelas 1 Sekolah Dasar untuk mengetahui Huruf Hijaiyah, menyebutkan Huruf Hijaiyah, dan melafalkan Huruf Hijaiyah.

\section{METODE PENGEMBANGAN}

Jenis penelitian ini adalah penelitian pengembangan karena mengembangkan multimedia pembelajaran interaktif pada mata pelajaran Pendidikan Agama Islam tema pengenalan Huruf Hijaiyah. Penelitian pengembangan ini dilaksanakan untuk menghasilkan suatu multimedia pembelajaran interaktif yang selanjutnya diujicobakan efektifitas, efisiensi, dan daya tarik dari multimedia tersebut.

Model pengembangan multimedia pembelajaran interaktif pada mata pelajaran Pendidikan Agama Islam tema pengenalan Huruf Hijaiyah dapat menggunakan model Kemp dan Dayton, di mana langkah-langkah dalam pengembangan media pembelajaran harus melalui beberapa tahap, yaitu menentukan: (1) ide atau tujuan umum pembelajaran, (2) tujuan khusus pembelajaran, (3) karakteristik audiens, (4) isi materi (content outline), (5) treatment, (6) storyboard, (7) naskah (script), (8) developing, editing, and mixing, dan (9) testing and revising. Khusus pada tahap developing, editing, and mixing di atas pengembang menggunakan program komputer yaitu Adobe Flash CS3.

Kegiatan uji coba dilakukan sebagai evaluasi formatif mengenai kelayakan multimedia ditinjau dari efektifitas, efisiensi, dan daya tarik. Subjek uji coba adalah sasaran pengguna produk pengembangan yaitu peserta didik Kelas 1 SDN Socah 3 Bangkalan dengan jumlah 39 peserta didik. Dalam uji coba ini sasaran peserta didik yang dibutuhkan adalah 3 peserta didik untuk uji coba perorangan, 9 peserta didik untuk uji coba kelompok kecil, dan 27 peserta didik untuk uji kelompok besar (uji lapangan).

\section{HASIL PENGEMBANGAN DAN PEMBAHASAN}

Hasil penelitian pada pengembangan ini adalah berupa multimedia pembelajaran interaktif yang berfungsi sebagai media dalam pembelajaran Huruf Hijaiyah untuk peserta didik Kelas 1 SD. Adapun hasil pengembangan yang menggunakan Adobe Flash CS3 ini dapat ditunjukkan dipaparkan dari gambar berikut ini: 

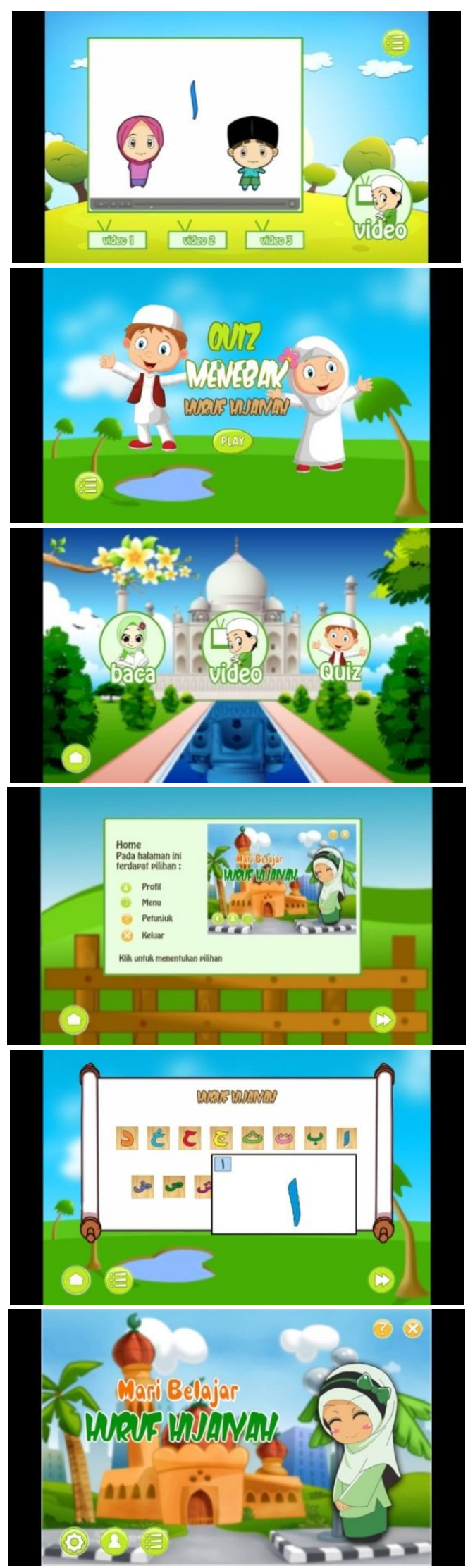

Gambar 1. Beberapa screenshot dalam multimedia pembelajaran interaktif
Untuk menganalisis data yang terkumpul dari angket maka akan digunakan analisis statistik deskriptif. Data dari angket akan dianalisis untuk mendapatkan gambaran tentang multimedia pembelajaran yang dikembangkan. Setelah angket terkumpul maka akan dihitung prosentase dari tiap-tiap butir pertanyaan pada angket dengan rumus menurut Komang I. Sudarman (2006) adalah sebagai berikut:

Prosentase jawaban

$$
=\frac{\sum(\text { jawaban } \mathrm{x} \text { bobot tiap pilihan })}{\mathrm{n} \times \mathrm{bobot} \text { tertinggi }} \times 100 \%
$$

Keterangan:

$\mathrm{F}=$ Frekuensi subjek yang memilih alternatif jawaban

$\mathrm{n}=$ Jumlah keseluruhan item angket

Pemberian makna dan pengambilan keputusan tentang kualitas produk multimedia pembelajaran interaktif ini akan menggunakan konversi tingkat pencapaian dengan skala 5 seperti tabel 3.1 di bawah ini:

Tabel 1. Konversi Tingkat Pencapaian dan Kualifikasi

\begin{tabular}{|c|l|l|}
\hline $\begin{array}{c}\text { Tingkat } \\
\text { Pencapaian }\end{array}$ & Kualifikasi & Keterangan \\
\hline $90 \%-100 \%$ & Sangat tinggi & $\begin{array}{l}\text { Sangat layak, media } \\
\text { tidak perlu direvisi }\end{array}$ \\
\hline $75 \%-89 \%$ & Tinggi & $\begin{array}{l}\text { Layak, media tidak } \\
\text { perlu direvisi }\end{array}$ \\
\hline $65 \%-74 \%$ & Cukup tinggi & $\begin{array}{l}\text { Kurang layak, media } \\
\text { perlu direvisi }\end{array}$ \\
\hline $55 \%-64 \%$ & Kurang tinggi & $\begin{array}{l}\text { Tidak layak, media } \\
\text { perlu direvisi }\end{array}$ \\
\hline $0 \%-54 \%$ & $\begin{array}{l}\text { Sangat kurang } \\
\text { tinggi }\end{array}$ & $\begin{array}{l}\text { Sangat tidak layak, } \\
\text { media perlu direvisi }\end{array}$ \\
\hline
\end{tabular}

Hasil analisis data ini akan digunakan untuk merevisi produk pengembangan, mengkaji produk, dan memberikan saran pemanfaatan serta pengembangan lebih lanjut.

Dari pengembangan yang telah diciptakan maka dilakukan uji coba produk tersebut pada siswa Kelas 1 SDN Socah 3 Bangkalan untuk mengetahui efektifitas, efisiensi, dan daya tarik media. Dari uji coba produk baik secara perorangan, kelompok kecil, dan kelompok besar didapat data sebagai berikut: 
Tabel 2. Komponen-Komponen yang Dinilai Pada Uji Coba Perorangan

\begin{tabular}{|c|l|c|c|c|c|}
\hline No. & \multicolumn{1}{|c|}{ Komponen yang dinilai } & $\begin{array}{c}\text { Skor dari } \\
\text { responden }\end{array}$ & $\begin{array}{c}\text { Jumlah }\left(\sum\right) \\
\text { skor }\end{array}$ & $\begin{array}{c}\text { Rata-rata skor } \\
\text { ( skor/ } \\
\text { responden) }\end{array}$ & $\begin{array}{c}\text { Presentase } \\
(\%)\end{array}$ \\
\hline 1. & $\begin{array}{l}\text { Kemampuan } \\
\text { multimedia pembelajaran interaktif berbasis } \\
\text { komputer mampu menyampaikan materi-materi } \\
\text { pelajaran huruf hijaiyah. }\end{array}$ & 444 & 12 & 4 & $80 \%$ \\
\hline 2. & $\begin{array}{l}\text { Kejelasan isi materi-materi pada multimedia } \\
\text { pembelajaran interaktif }\end{array}$ & 445 & 13 & 4,3 & $86 \%$ \\
\hline 3. & $\begin{array}{l}\text { Kejelasan animasi pada multimedia pembelajaran } \\
\text { interaktif berbasis komputer }\end{array}$ & 444 & 12 & 4 & $80 \%$ \\
\hline 4. & $\begin{array}{l}\text { Kejelasan teks pada multimedia pembelajaran } \\
\text { interaktif berbasis komputer }\end{array}$ & 455 & 14 & 4,7 & $93 \%$ \\
\hline 5. & $\begin{array}{l}\text { Kemampuan multimedia pembelajaran interaktif } \\
\text { untuk memudahkan siswa dalam belajar }\end{array}$ & 545 & 14 & 4,7 & $93 \%$ \\
\hline 6. & $\begin{array}{l}\text { Kemudahan saat mengoperasikan atau menjalankan } \\
\text { multimedia pembelajaran interaktif }\end{array}$ & 545 & 14 & 4,7 & $93 \%$ \\
\hline 7. & $\begin{array}{l}\text { Tampilan visual (gambar, video, atau animasi) } \\
\text { dalam memudahkan siswa saat belajar }\end{array}$ & 544 & 13 & 4,3 & $86 \%$ \\
\hline 8. & $\begin{array}{l}\text { Daya tarik audio (musik, efek suara, atau narasi) } \\
\text { dalam multimedia pembelajaran interaktif berbasis } \\
\text { komputer }\end{array}$ & 454 & 13 & 4,3 & $86 \%$ \\
\hline 9. & $\begin{array}{l}\text { Tampilan teks dan bentuk tulisan (font) dalam } \\
\text { multimedia pembelajaran interaktif berbasis } \\
\text { komputer }\end{array}$ & 545 & 14 & 4,7 & $93 \%$ \\
\hline 10. & $\begin{array}{l}\text { Kombinasi, tatanan, dan pemilihan warna dalam } \\
\text { multimedia pembelajaran interaktif }\end{array}$ & 455 & 14 & 4,7 & $93 \%$ \\
\hline & \multicolumn{1}{|c|}{ Rata-rata prosentase keseluruhan } & & $88,3 \%$ \\
\hline
\end{tabular}

Tabel 3. Komponen-Komponen yang Dinilai pada Uji Coba Kelompok Kecil

\begin{tabular}{|c|c|c|c|c|c|}
\hline No. & Komponen yang dinilai & $\begin{array}{l}\text { Skor dari } \\
\text { responden }\end{array}$ & $\begin{array}{l}\text { Jumlah }\left(\sum\right) \\
\text { skor }\end{array}$ & 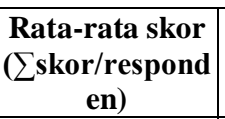 & $\begin{array}{l}\text { Presentase } \\
\quad(\%)\end{array}$ \\
\hline 1. & $\begin{array}{l}\text { Kemampuan } \\
\text { multimedia pembelajaran interaktif berbasis } \\
\text { komputer mampu menyampaikan materi-materi } \\
\text { pelajaran huruf hijaiyah. }\end{array}$ & $\begin{array}{c}4455544 \\
44\end{array}$ & 39 & 4,3 & $86 \%$ \\
\hline 2. & $\begin{array}{l}\text { Kejelasan isi materi-materi pada multimedia } \\
\text { pembelajaran interaktif }\end{array}$ & $\begin{array}{l}5455455 \\
55\end{array}$ & 43 & 4,7 & $94 \%$ \\
\hline 3. & $\begin{array}{l}\text { Kejelasan animasi pada multimedia pembelajaran } \\
\text { interaktif berbasis komputer }\end{array}$ & $\begin{array}{c}4444455 \\
45\end{array}$ & 39 & 4,3 & $86 \%$ \\
\hline 4. & $\begin{array}{l}\text { Kejelasan teks pada multimedia pembelajaran } \\
\text { interaktif berbasis komputer }\end{array}$ & $\begin{array}{c}5554444 \\
44\end{array}$ & 39 & 4,3 & $86 \%$ \\
\hline 5. & $\begin{array}{l}\text { Kemampuan multimedia pembelajaran interaktif } \\
\text { untuk memudahkan siswa dalam belajar }\end{array}$ & $\begin{array}{c}4444555 \\
44\end{array}$ & 39 & 4,3 & $86 \%$ \\
\hline 6. & $\begin{array}{l}\text { Kemudahan saat mengoperasikan atau menjalankan } \\
\text { multimedia pembelajaran interaktif }\end{array}$ & $\begin{array}{c}4545455 \\
44\end{array}$ & 40 & 4,4 & $88 \%$ \\
\hline 7. & $\begin{array}{l}\text { Tampilan visual (gambar, video, atau animasi) } \\
\text { dalam memudahkan siswa saat belajar }\end{array}$ & $\begin{array}{c}4445455 \\
45 \\
\end{array}$ & 40 & 4,4 & $88 \%$ \\
\hline 8. & $\begin{array}{l}\text { Daya tarik audio (musik, efek suara, atau narasi) } \\
\text { dalam multimedia pembelajaran interaktif berbasis } \\
\text { komputer }\end{array}$ & $\begin{array}{c}4455544 \\
44\end{array}$ & 39 & 4,3 & $86 \%$ \\
\hline 9. & $\begin{array}{l}\text { Tampilan teks dan bentuk tulisan (font) dalam } \\
\text { multimedia pembelajaran interaktif berbasis } \\
\text { komputer }\end{array}$ & $\begin{array}{c}3555554 \\
44\end{array}$ & 40 & 4,4 & $88 \%$ \\
\hline 10. & $\begin{array}{l}\text { Kombinasi, tatanan, dan pemilihan warna dalam } \\
\text { multimedia pembelajaran interaktif }\end{array}$ & $\begin{array}{c}4443555 \\
55\end{array}$ & 40 & 4,4 & $88 \%$ \\
\hline \multicolumn{5}{|c|}{ Rata-rata prosentase keseluruhan } & $87,6 \%$ \\
\hline
\end{tabular}


Tabel 4. Komponen-Komponen yang Dinilai pada Uji Coba Kelompok Besar

\begin{tabular}{|c|c|c|c|c|c|}
\hline No. & Komponen yang dinilai & $\begin{array}{l}\text { Skor dari } \\
\text { responden }\end{array}$ & $\begin{array}{l}\text { Jumlah }\left(\sum\right) \\
\text { skor }\end{array}$ & \begin{tabular}{|c|}
$\begin{array}{c}\text { Rata-rata skor } \\
\left(\sum \text { skor/respond }\right. \\
\text { en) }\end{array}$ \\
\end{tabular} & $\begin{array}{l}\text { Presentase } \\
\quad(\%)\end{array}$ \\
\hline 1. & $\begin{array}{l}\text { Kemampuan } \\
\text { multimedia pembelajaran interaktif berbasis } \\
\text { komputer mampu menyampaikan materi-materi } \\
\text { pelajaran huruf hijaiyah. }\end{array}$ & $\begin{array}{c}4445454 \\
5445554 \\
4555555 \\
455444\end{array}$ & 122 & \begin{tabular}{|l|}
4,5 \\
\end{tabular} & $90 \%$ \\
\hline 2. & $\begin{array}{l}\text { Kejelasan isi materi-materi pada multimedia } \\
\text { pembelajaran interaktif }\end{array}$ & $\begin{array}{l}5454444 \\
4445454 \\
4545444 \\
445545\end{array}$ & 117 & 4,3 & $86 \%$ \\
\hline 3. & $\begin{array}{l}\text { Kejelasan animasi pada multimedia pembelajaran } \\
\text { interaktif berbasis komputer }\end{array}$ & $\begin{array}{l}5445554 \\
5455444 \\
4445454 \\
455555\end{array}$ & 122 & 4,5 & $90 \%$ \\
\hline 4. & $\begin{array}{l}\text { Kejelasan teks pada multimedia pembelajaran } \\
\text { interaktif berbasis komputer }\end{array}$ & $\begin{array}{c}5454444 \\
4445454 \\
4545444 \\
445545\end{array}$ & 117 & 4,3 & $86 \%$ \\
\hline 5. & $\begin{array}{l}\text { Kemampuan multimedia pembelajaran interaktif } \\
\text { untuk memudahkan siswa dalam belajar }\end{array}$ & $\begin{array}{l}5445554 \\
4445454 \\
5455444 \\
455555\end{array}$ & 122 & 4,5 & $90 \%$ \\
\hline 6. & $\begin{array}{l}\text { Kemudahan saat mengoperasikan atau menjalankan } \\
\text { multimedia pembelajaran interaktif }\end{array}$ & $\begin{array}{l}4445454 \\
5445554 \\
5455444 \\
455555\end{array}$ & 122 & 4,5 & $90 \%$ \\
\hline 7. & $\begin{array}{l}\text { Tampilan visual (gambar, video, atau animasi) } \\
\text { dalam memudahkan siswa saat belajar }\end{array}$ & $\begin{array}{c}4545444 \\
4445454 \\
5454444 \\
445545\end{array}$ & 117 & 4,3 & $86 \%$ \\
\hline 8. & $\begin{array}{l}\text { Daya tarik audio (musik, efek suara, atau narasi) } \\
\text { dalam multimedia pembelajaran interaktif berbasis } \\
\text { komputer }\end{array}$ & $\begin{array}{l}4545444 \\
4445454 \\
5454444 \\
445545\end{array}$ & 117 & 4,3 & $86 \%$ \\
\hline 9. & $\begin{array}{l}\text { Tampilan teks dan bentuk tulisan (font) dalam } \\
\text { multimedia pembelajaran interaktif berbasis } \\
\text { komputer }\end{array}$ & $\begin{array}{l}4545444 \\
4445454 \\
5454444 \\
445545\end{array}$ & 117 & 4,3 & $86 \%$ \\
\hline 10. & $\begin{array}{l}\text { Kombinasi, tatanan, dan pemilihan warna dalam } \\
\text { multimedia pembelajaran interaktif }\end{array}$ & $\begin{array}{c}5445554 \\
4445454 \\
5455444 \\
455555 \\
\end{array}$ & 122 & 4,5 & $90 \%$ \\
\hline \multicolumn{5}{|c|}{ Rata-rata prosentase keseluruhan } & $88 \%$ \\
\hline
\end{tabular}

Dari data yang dihasilkan saat uji coba perorangan yang terdiri dari tiga siswa Kelas 1 SDN Socah 3 Bangkalan diketahui bahwa ratarata prosentase secara keseluruhan mengenai kualitas multimedia pembelajaran interaktif pada tema pengenalan Huruf Hijaiyah adalah $88,3 \%$. Hal ini menunjukkan bahwa produk multimedia pembelajaran interaktif berada pada kualifikasi "tinggi" atau "baik" dan tidak memerlukan revisi.

Dari data yang dihasilkan saat uji coba kelompok kecil yang terdiri dari sembilan siswa Kelas 1 SDN Socah 3 Bangkalan diketahui bahwa rata-rata prosentase secara keseluruhan mengenai kualitas multimedia pembelajaran interaktif pada tema pengenalan Huruf Hijaiyah adalah 87,6\%. Hal ini menunjukkan bahwa produk multimedia pembelajaran interaktif berada pada kualifikasi "tinggi" atau "baik" dan tidak memerlukan revisi.

Dari data yang dihasilkan saat uji coba kelompok besar yang terdiri dari dua puluh tujuh siswa Kelas 1 SDN Socah 3 Bangkalan 
diketahui bahwa rata-rata prosentase secara keseluruhan mengenai kualitas multimedia pembelajaran interaktif pada tema pengenalan Huruf Hijaiyah adalah $88 \%$. Hal ini menunjukkan bahwa produk multimedia pembelajaran interaktif pada berada pada kualifikasi "tinggi" atau "baik" dan tidak memerlukan revisi.

\section{KESIMPULAN DAN SARAN}

Dari hasil pengembangan yang telah dilakukan, maka multimedia pembelajaran interaktif ini telah berhasil diuji tingkat efektifitas, efisiensi, dan daya tariknya. Di mana dari penelitian tersebut pengembang telah mendapatkan data yang mendukung bahwa produk yang dikembangkan ini telah layak digunakan dalam proses pembelajaran karena memiliki nilai efektifitas, efisiensi, dan daya tarik yang tinggi untuk digunakan dalam pembelajaran. Hal ini terbukti dengan prosentase angket tanggapan atau penilaian peserta didik terhadap multimedia pembelajaran interaktif yang berada pada angka $88 \%$ pada uji coba kelompok besar yang berarti berada dalam kualifikasi tinggi dan media layak digunakan tanpa direvisi.

Produk pengembangan berupa multimedia pembelajaran interaktif ini dapat digunakan sebagai sumber dalam meningkatkan strategi penyampaian pesan atau strategi mengajar guru agar lebih inovatif dan bermutu. Dengan multimedia pembelajaran interaktif ini maka guru dan siswa tidak akan terpaku pada buku tematik saja, melainkan ada media baru yang lebih lengkap dan menyajikan pembelajaran yang menyenangkan. Selain itu, instrumeninstrumen tambahan dalam multimedia (seperti: musik, gambar, animasi, dan efek suara) dapat menarik perhatian siswa dan menghilangkan kebosanan dalam belajar, justru multimedia ini dapat meningkatkan keinginan lebih siswa untuk belajar dan siswa ingin belajar terus menerus.

Saran pemanfaatan produk dari pengembang yang berkaitan dengan multimedia pembelajaran interaktif pada mata pelajaran Pendidikan Agama Islam tema pengenalan Huruf Hijaiyah adalah sebagai berikut:

a. Produk ini disarankan dalam kegiatan pembelajaran agar guru lebih kreatif dalam menyampaikan materi kepada siswa, menampilkan pembelajaran yang inovatif, tidak membosankan bagi siswa, dan lebih memudahkan siswa untuk memahami materi mata pelajaran Pendidikan Agama Islam tema pengenalan Huruf Hijaiyah.

b. Produk multimedia pembelajaran interaktif pada mata pelajaran Pendidikan Agama Islam tema pengenalan Huruf Hijaiyah ini akan lebih baik manfaatnya jika baik guru dan siswa sudah tahu bagaimana mengoperasikan multimedia ini.

c. Produk ini dapat digunakan sebagai media, alat, atau sarana dalam strategi penyampaian pesan pada proses pembelajaran dari seorang guru kepada siswanya yang membuat pembelajaran lebih bermakna dan menyenangkan bagi siswa.

d. Produk ini dalam pemanfaatannya harus didukung dengan tersedianya perangkat yang baik dan lengkap seperti: komputer atau laptop, $L C D$ projector, screen, dan speaker.

\section{DAFTAR PUSTAKA}

Anwas, Oos M. 2003. Model Inovasi ELearning Dalam Meningkatkan Mutu Pendidikan. Jurnal Teknodik: Edisi No.12/VII/Oktober/2003.

Degeng, I Nyoman, S. 1989. Teori Pembelajaran 1: Taksonomi Variabel. Malang: Universitas Negeri Malang.

Degeng, I Nyoman, S. 1990. Teori Pembelajaran 2: Terapan. Malang: Universitas Negeri Malang.

Degeng, I Nyoman, S. 1994. Teknologi Pembelajaran: Definisi dan 
Kawasannya Malang: Universitas Youtube.

Negeri Malang.

Hartanto, Antonius Aditya dan Onno W. Purbo. 2002. E-Learning berbasis PHP dan MySQL. Jakarta: Elex Media Komputindo.

Kemp, Jerrold E., dan Dayton, Deane K. 1985. Planning And Producing Instructional Media. New York: Harper \& Row Publisher Inc.

Ramansyah, Wanda. 2010. Pengembangan Multimedia Pembelajaran Interaktif Berbasis Komputer Pada Mata Diklat Dasar-Dasar Mesin. Tesis tidak diterbitkan. PPS Universitas Negeri Malang.

Richard A. Schwier dan Earl R. Misanchuk. (1993). Interactive Multimedia Instruction. New Jersey : Educational Technology Publications.

Rob Phillips. (1997). The Developer's Handbooks to Interactive Multimedia:

A Practice Guide for Educational Applications. London: Kogan Page Limited.

Sadiman, Arief, S. 2008. Media Pendidikan: Pengertian, Pengembangan, dan Pemanfaatannya. Jakarta: PT. Raja Grafindo Persada.

Saepudin, Asep. 2003. Penerapan Teknologi Informasi Dalam Pendidikan Masyarakat. Jurnal Teknodik: Edisi No.12/VII/Oktober/2003.

Seels, Barbara., dan Glasgow, Zita. 1998. Making Instructional Design Decisions. NewJersey: Prentice Hall Inc.

Slavin, Robert E. 2008. Psikologi Pendidikan: Teori dan Praktek. Jakarta: PT. Indeks.

Smaldino, Sharon E. 2008. Instructional Technology and Media for Learning. New Jersey: Pearson Education Ltd.

Soekartawi. 2003. Prinsip Dasar E-Learning: Teori Dan Aplikasinya Di Indonesia. Jurnal Teknodik: Edisi No.12/VII/Oktober/2003. 